\title{
The analytical performance of a real time BKV PCR assay
}

\author{
Real time BKV PCR testinin analitik performansı
}

Nevgün SEPIN-ÖZEN ${ }^{1}, \quad$ Derya MUTLU², $\quad$ Dilek ÇOLAK², Duygu DAĞLAR ${ }^{2}, \quad$ Akın YEŞiLKAYA ${ }^{4}$

\section{ABSTRACT}

Objective: BKV is a virus usually undergone asymptomatically in the childhood and can remain latent in the peripheral blood, brain and especially in kidneys. Reactivation of BKV under immunosuppression can cause diseases like interstitial nephritis, haemorrhagic or non- haemorrhagic cystitis, ureterostenosis and nephropathy. Especially in transplant recipients nephropathy frequency can reach $5 \%$ and can be the cause of premature loss $30-60 \%$ of transplanted organs and poor outcome. Quantification of BKV viral load in urine and serum with real time polymerase chain reaction (PCR) plays important role for early diagnosis and management of the therapy. Since the Real time PCR assay is more sensitive than classical PCR, can do quantification and have a less risk of contamination and short turn-around time. The aim of our study was to evaluate the analytical performance of a real time quantitative BKV PCR assay which was developed in our laboratory.

Method: Standards were prepared from BKV plasmid (ATCC 45025). BKV plasmid that contained $15 \times 10^{7}$ copies/ $\mathrm{ml}$ to $3 \times 10^{1}$ copies/ml serial dilutions was measured by spectrofotometery. Primers for BKV VP1 gene and dual labelled probe at the 5' end with 6-carboxyfluoresceine (FAM) and the 3' end with 6-carboxytetramethylrhodamine (TAMRA) as described previously were used for the amplification reactions.

\section{ÖZET}

Amaç: BKV, çocukluk çağında genellikle asemptomatik olarak geçirilen ve özellikle böbreklerde olmak üzere perifik kan ve beyinde latent olarak kalabilen bir virustür. BVK'nın aktivasyonu immünsuprasyonu olan hastalarda hemorajik veya hemorajik olmayan sistit, ürostenoz ve nefropatiye neden olabilir. Özellikle transplant alıcılarında nefropati sıklığı \%5'lere kadar ulaşabilmekte ve transplante edilen organın \%30-60 erken kaybı ve kötü bir klinik seyirle sonuçlanabilmektedir. $B K V$ viral yükünün serum ve idrar örneklerinde polimeraz zincir reaksiyonu (PZR) ile kantitasyonu, erken tanı ve tedavinin yönetiminde önemli rol oynamaktadır. Real time PZR; klasik PZR'ye göre daha duyarlı, kantitasyon yapabilen, kontaminasyon riski az ve sonuçlanma süresinin kısa olması nedeniyle son yıllarda yaygın olarak kullanılmaktadır. Bu çalıșmamızda BKV tanısı için laboratuvarımızda tasarlanan kantitatif real time BKV PZR testinin analitik performansının değerlendirilmesi amaçlanmıștır.

Yöntem: BKV plazmidinden (ATCC 45025) standardlar hazırlanmıștır. $15 \times 10^{7}$ kopya/ml'den $3 \times 10^{1} \mathrm{kopya} / \mathrm{ml}$ 'ye kadar seri dilüsyonlar içeren BKV plazmidinin spektrofotometrik ölçümü yapılmıștır. Amplifikasyon reaksiyonları için BKV VP1 gen bölgesine uygun, 5' ucu 6-karboksifloreseinle (FAM), 3' ucu 6-karboksitetrametilrodamin (TAMRA) ile ișaretli primerler daha önce belirtildiği gibi kullanılmıștır.

${ }^{1}$ Antalya Public Health Laboratory, Clinical Microbiology, ANTALYA, TURKEY

${ }^{2}$ Akdeniz University, Medical Faculty Department of Medical Microbiology, ANTALYA, TURKEY

${ }^{3}$ Aydin State Hospital, Clinical Microbiology, ANTALYA, TURKEY

${ }^{4}$ Akdeniz University, Medical Faculty Department of Biochemistry, ANTALYA, TURKEY

İletişim/Corresponding Author: Nevgün SEPIN-ÖZEN

Antalya Public Health Laboratory, Clinical Microbiology, ANTALYA, TURKEY

Tel : +902422370390

E-posta/E-mail : nevgun@gmail.com

Geliş Tarihi / Received : 20.03.2015

Kabul Tarihi / Accepted : 30.07.2015

DOI ID : 10.5505/TurkHijyen.2015.92603

Sepin-Özen N, Mutlu D, Çolak D, Dağlar D, Yeșilkaya A. The analytical performance of a real time BKV PCR assay. Turk Hij Den Biyol Derg, 2015; 72(4): 297-302. 
Results: To evaluate the analytical performance of the assay; analytical sensitivity, specificity, linearity, accuracy and precision was determined. The analytical sensitivity and the limit of detection of the assay were found $15 \times 10^{2}$ copies $/ \mathrm{ml}$ and $5 \times 10^{2}$ copies/ $\mathrm{ml}$, respectively. Standard deviation (SD) of dilutions varied from 0.02 to 0.644 and CV varied from $0.79 \%$ to $11.47 \%$ between $15 \times 10^{7}$ to $15 \times 10^{1}$ copies $/ \mathrm{ml}$ concentrations. Nineteen proficiency samples results of quality control program were in close agreement $(100 \%)$. The assay demonstrated a linear range from $15 \times 10^{2}$ to $15 \times 10^{8}$ copies $/ \mathrm{ml}$. Specificity of the assay was found $100 \%$. In addition proficiency samples results of the external quality control program were in close agreement.

Conclusion: According to our results the real time PCR protocol of BKV developed in our laboratory was found sensitive, specific, precise and reproducible with a broad dynamic range.

Key Words: Analytical performance, Real Time BKV $\mathrm{PCR}$, validation experiments
Bulgular: Çalıșmada testin analitik performansının değerlendirilmesi için analitik duyarlılık, özgüllük, doğrusallık, doğruluk ve kesinlik parametreleri belirlenmiștir. Testin analitik sensitivitesi $15 \times 10^{2}$ kopya/ml ve saptama limiti $5 \times 10^{2} \mathrm{kopya} / \mathrm{ml}$ olarak belirlenmiștir. $15 \times 10^{7}$ kopya/ml ile $15 \times 10^{1}$ kopya/ $\mathrm{ml}$ konsantrasyonlar arasında çalıșılan dilüsyonların standard deviasyonu (SD) 0,02 ile 0,644 arasında, varyasyon katsayısı (CV) ise \%0,79 ile \%11,47 arasında değișmiștir. 19 dıș kalite kontrol örneğinin sonuçları ilgili programla \%100 uyumludur. Testimiz $15 \times 10^{2}$ kopya/ml ile $15 \times 10^{8} \mathrm{kopya} / \mathrm{ml}$ arasında lineer bir seyir göstermiștir. Özgüllüğü ise \%100 olarak belirlenmiștir. Ayrıca dıș kalite kontrol programı ile kalite kontrol örneklerinin sonuçları çok yakın uygunluktadır.

Sonuç: Elde edilen sonuçlarımız doğrultusunda laboratuvar tasarımlı real time PCR protokolümüz; duyarlı, özgül, kesin ve geniș dinamik aralıklı tekraralanabilirliği olan bir test olarak bulunmuștur.

Anahtar Kelimeler: Analitik performans, Real Time BKV PCR, Validasyon deneyleri

\section{INTRODUCTION}

BK virus (BKV) infection typically occurs in early childhood. Following primary infection, BKV establishes subclinical and persistent infection of which predominantly remains in kidneys, peripheral blood and brain $(1,2)$. Reactivation of BKV under immunosuppression is associated with diseases such as interstitial nephritis, haemorrhagic and non-haemorrhagic cystitis, ureterostenosis and nephropathy (1-3). Usually in transplant recipients BKV associated nephropathy (BKVAN), leading to graft loss in $50 \%$ of infected patients within 2-3 years of follow-up and subsequent return to haemodialysis $(4,5)$. Progression of BKVAN often occurs without clinical signs or symptoms except a decline in renal function $(4,6)$. Monitarization of BKV infection after transplantation can facilitate early diagnosis which provides an opportunity for pre-emptive treatment $(6,7)$.
For the diagnosis of BKV related conditions cytological analysis of urine samples, urine cell culture and electron microscopy is widely used but they are time-consuming and lack sensitivity $(8,9)$. Quantification of BKV viral load by a PCR based method has a prognostic value for diagnosis of BKV related diseases and monitoring $(3,4,6)$. The aim of our study was to evaluate the analytical performance of a real time quantitative BKV PCR assay which was developed in our laboratory.

\section{MATERIALS and METHODS}

For the evaluation of analytical performance; analytical sensitivity, specificity, linearity, accuracy and precision were determined. Standard curves for the quantification of BKV were constructed using five, ten fold serial dilutions of a plasmid containing 
the entire linearized genome of the BK virus Dunlop strain inserted into the Bam $\mathrm{H} 1$ restriction site of the pBR322 plasmid (pBKV, ATCC 45025). The plasmid was amplified using a transfection system. Plasmids were selected and isolated from competent bacteria and to determine concentrations a ultraviolet spectrofotometer was used. Serial dilutions of BKV plasmid that contained $15 \times 10^{7}$ copies $/ \mathrm{ml}$ to $3 \times$ $10^{1}$ copies $/ \mathrm{ml}$ were measured by spectrofotometery. Every dilutions were tested three times in the same run and different runs. Totaly standards prepared from BKV plasmid were tested 19 times in different runs. According to the assay results mean of measured BKV DNA levels, standard deviation and coefficient of variation values were calculated (Table 1). Primers for BKV VP1 gene and dual labelled probe at the 5' end with 6- carboxyfluoresceine (FAM) and the 3' end with 6-carboxytetramethylrhodamine (TAMRA) as described previously were used for the amplification reactions $(10)$.
Analytical sensitivity: $15 \times 10^{7}$ copies $/ \mathrm{ml}$ to $3 \times$ $10^{1}$ copies $/ \mathrm{ml}$ serial dilutions were studied as three replicates in the same run and three different runs. Totally each dilutions were tested nine times for the analytical sensitivity.

Linearity: Three replicates of dilutions containing $15 \times 10^{7}$ copies $/ \mathrm{ml}$ to $15 \times 10^{1}$ copies $/ \mathrm{ml}$ were studied in 4 different runs. Totally each dilutions were tested 12 times.

Precision and accuracy: $15 \times 10^{7}$ copies $/ \mathrm{ml}$ to $15 \times 10^{1}$ copies/ml dilutions were studied as three replicates in the same run and 19 times in different runs.

Specificity: The specificity of the assay was assassed by the testing of 66 BKV negative human plasma samples. We participated to the external quality control program of Quality Control for Molecular Diagnostics (QCMD) and QCMD 2007 JC virus and BK virus DNA External Quality Assessment (EQA) Panel samples were tested.

Table 1. Serial dilutions of the plasmid and their standard deviation and coefficient of variation values

\begin{tabular}{|c|c|c|c|c|c|}
\hline $\begin{array}{l}\text { Target Value } \\
\text { (copies/ml) }\end{array}$ & $\begin{array}{l}\text { Target value } \\
\left(\log _{10}\right)\end{array}$ & $\begin{array}{c}\text { Number of } \\
\text { determinations } \\
\text { (n) }\end{array}$ & $\begin{array}{l}\text { Mean of Measured } \\
\text { BKV DNA }\left(\log _{10}\right)\end{array}$ & $\begin{array}{l}\text { Standard } \\
\text { deviation }\end{array}$ & $\begin{array}{l}\text { Coefficient of } \\
\text { variation (\%) }\end{array}$ \\
\hline $15 \times 10^{7}$ & 8.17 & 3 & 8.11 & 0.07 & 0.88 \\
\hline $15 \times 10^{6}$ & 7.17 & 3 & 7.24 & 0.08 & 1.2 \\
\hline $15 \times 10^{5}$ & 6.17 & 3 & 5.74 & 0.1 & 1.87 \\
\hline $15 \times 10^{4}$ & 5.17 & 3 & 4.99 & 0.07 & 1.54 \\
\hline $15 \times 10^{3}$ & 4.17 & 3 & 4.01 & 0.09 & 2.35 \\
\hline $15 \times 10^{2}$ & 3.17 & 3 & 3.06 & 0.24 & 8.08 \\
\hline $15 \times 10^{1}$ & 2.17 & 3 & 3.14 & 0.02 & 0.79 \\
\hline $15 \times 10^{7}$ & 8.17 (standard 1) & 19 & 8.13 & 0.06 & 0.84 \\
\hline $15 \times 10^{6}$ & 7.17 (standard 2) & 19 & 7.25 & 0.104 & 1.44 \\
\hline $15 \times 10^{5}$ & 6.17 (standard 3) & 19 & 5.61 & 0.644 & 11.47 \\
\hline
\end{tabular}


Statistical analysis: Descriptive statisticaly analysis was performed with Microsoft Excell 2003 version, using the database of assay.

\section{RESULTS}

For absolute quantification; standards 1, 2, 3 containing known input gene copy numbers were analyzed in each run.

Analytical sensitivity of the assay was assessed by testing $15 \times 10^{7}$ copies $/ \mathrm{ml}$ to $15 \times 10^{2}$ copies $/ \mathrm{ml}$ dilutions 9 times in different runs. All replicates were found positive. Four of the 9 replicates were positive for $15 \times 10^{2}$ copies $/ \mathrm{ml}$ to $1 \times 10^{3}$ copies $/ \mathrm{ml}$ dilutions. No positivity were found for the dilutions of $3 \times 10^{2}$ copies/ $\mathrm{ml}$ to $3 \times 10^{1}$ copies $/ \mathrm{ml}$. The analytical sensitivity of the assay was found $15 \times 10^{2}$ copies $/ \mathrm{ml}$.

Limit of detection was found $5 \times 10^{2}$ copies $/ \mathrm{ml}$ greater than $95 \%$ positivity rate for all replicates with Microsoft Excell 2003 version. The results were expressed as target not detected below $5 \times 10^{2}$ copies $/ \mathrm{ml}$.

None of the 66 negative human plasma samples were positive, so the specificity of the assay was found $100 \%$.

To determine the linearity; the correlation coefficient ( $r$ ) and coefficient of variation (CV) were checked according to the results of $15 \times 10^{7}$ to $15 \times 10^{1}$ copies/ml dilutions. As shown in Figure 1 (Linearity plot) a significant relationship was found between the average measured and expected BKV DNA levels ( $r=0.9986$ and $\mathrm{p}<0.005)$. Precision and accuracy was determined by testing of serial dilutions. As shown in Table 1 standard deviation (SD) of dilutions varied from 0.02 to 0.644 and CV varied from $0.79 \%$ to $11.47 \%$ between $15 \times 10^{7}$ to 15 $x 10^{1}$ copies/ml concentrations. Nineteen proficiency samples results of quality control program were in close agreement (100\%). The assay demonstrated a linear range from $15 \times 10^{2}$ to $15 \times 10^{8}$ copies $/ \mathrm{ml}$.

\section{DISCUSSION}

Infections by BKV are gaining important clinical problem in the management of renal transplant patients because it can be the cause of BKVAN and consequently loss of the transplanted organ. Patients with BKVAN show evidence of viral activation, but all of them do not have any clinical sign or specific symptom, except a breakdown in renal function $(4,7)$. The efficient early diagnosis of BKVAN, with close monitoring of renal function could be the best strategy for early clinical intervention and efficient treatment, with

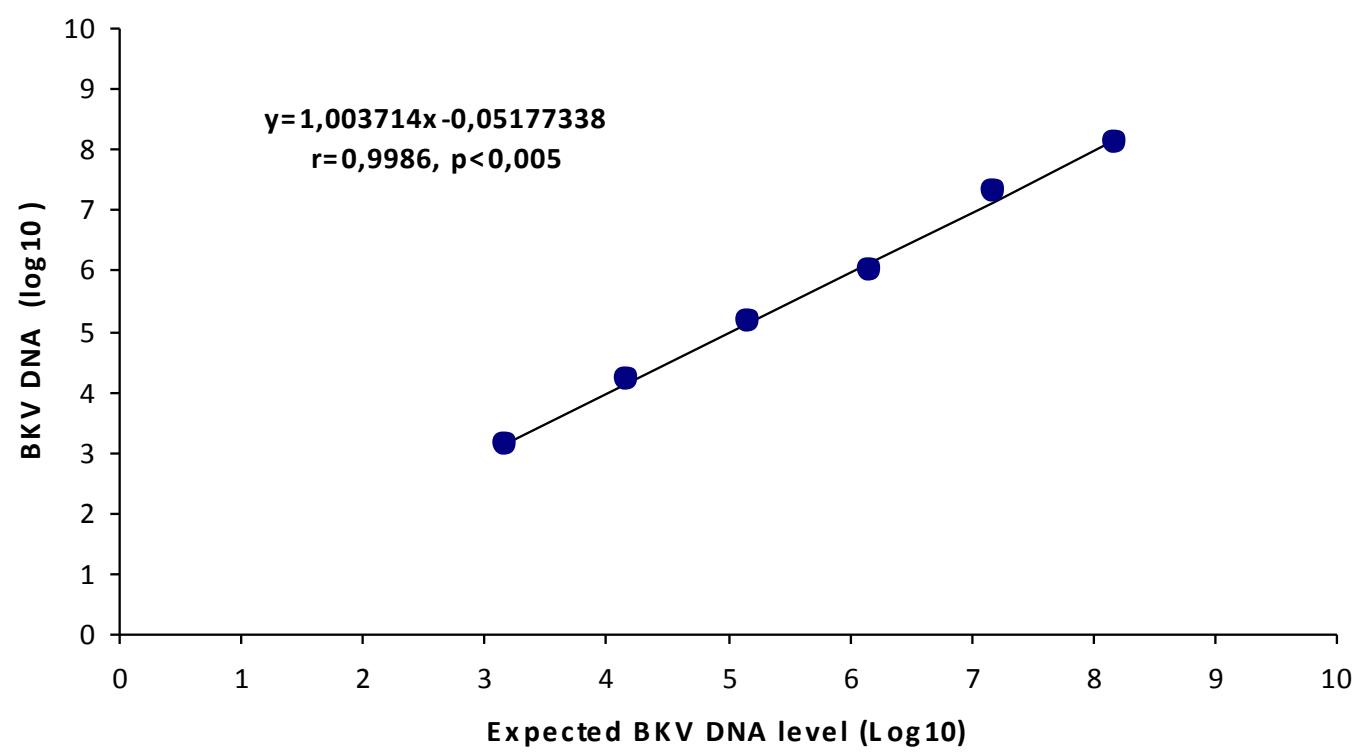

Figure 1. Scatter plot and regression equation 
benefits regarding damage progression and successfull outcome.

BKV quantitation by PCR is a key point on clinical management. The advantages of BKV quantitation is the early diagnosis with high predictive value, a window period of 6-12 weeks before viremia and nephropathy and being non invasive technic for patients comparison to renal biopsy (11). Recent studies have assessed the effectiveness of quantification of BKV and monitoring therapy to investigate the correlations between viral shedding and disease conditions (12-14). In fact, there is no effective antiviral agents for patients under immunosuppressive conditions $(2,15)$. Medical relevance of BKV infection is increasing among transplant patients due to immunosuppressive agents. For rapid diagnosis serial measurement of BKV viral load with real time PCR assay became a usefull diagnostic tool. Real time PCR assays have increased sensitivity and wide dynamic range compared to conventional PCR methods. Risk of contamination reduced during the analysis, early viral monitoring and the turn around time for resulting the reports within hours are the other advantages of real time PCR methods $(3,16-19)$. Quantification of viral load with laboratory developed tests must be ideally sensitive, specific, accurate, precise and have a broad dynamic range. When a new test is introduced to laboratory for routine diagnostic, validation experiments must be performed including the analytical sensitivity, specificity, precision, accuracy and linearity $(20,21)$. During the validation process stable control materials with known copies per mililiter are essantial. Even so there is no international standard material or method for quantitation of BKV viral load. Owing to this, laboratories must prepare their own internal standards for a measure of reproducibility and the analytical performance. In a study target sequences of BKV and CMV were diluted and used as external standard for the newly developed real time PCR assay detecting both CMV and BKV DNA simultaneously. After the evaluation process the sensitivity of the assay was found $5 \times 10^{3}$ copies $/ \mathrm{ml}$ (22). In a similar study by Wu et al., a new quantitative PCR method for detection of BKV and CMV DNA simultaneously was established and the sensitivity of the assay was found $5 \times 10^{3}$ copies $/ \mathrm{ml}$ (23). The analytical sensitivity of our assay was found $15 \times 10^{2}$ copies $/ \mathrm{ml}$. In several reports the sensitivity of BKV quantitation were found between $10^{1}$ to $10^{3}$ copies $/ \mathrm{ml}(20,21,24,25)$. For laboratory developed real time PCR assay the reportable range of viral load must be determined by measuring linear regression line and the correlation coefficient. Our PCR assay has a reportable range of $15 \times 10^{2}$ to $15 \times 10^{8}$ copies $/ \mathrm{ml}$. After validation experiments the laboratories must check the feasibility of the new test with an external quality control program. The intralaboratory variability can be tested by this quality control program material. In conclusion, this study shows that our real time PCR assay of BKV DNA is sensitive, specific, precise and reproducible and that it has a broad dynamic range of quantification. Analytical performance of the assay should be evaluated before the routine workflow for the standardization of laboratory developed real time PCR methods.

\section{REFERENCES}

1. Major EO, Ryschkewitsch C, Valsamakis A, Hou J. Human polyomaviruses. In: Murray PR, Baron EJ, Jorgensen JH, Landry ML, Pfaller MA, eds. Manual of clinical microbiology. 9th ed. Washington DC: ASM Pres, 2007: 1612-21.

2. Van Aalderen MC, Heutinck KM, Huisman C, Berge. IJM. BK virus infection in transplant recipients: Clinical manifestations, treatment options and the immune response. Neth J Med, 2012; 70: 172-83.
3. Mischitelli M, Fioriti D, Anzivino E, Bellizzi A, Ferretti G, Gussman N et al. BKV QPCR detection and infection monitoring in renal transplant recipients. New Microbiol, 2007; 30: 271-4.

4. Pollara CP, Corbellini S, Chiappini S, Sandrini S, Tomasi DD, Bonfanti C et al. Quantitative viral load measurement for BKV infection in renal transplant recipients as a predictive tool for BKVAN. New Microbiol, 2011; 34: 165-71. 
5. Anziviro E, Bellizzi A, Mitterhofer AP, Tinti F, Barile $M$, Colosimo MT et al. Early monitoring of the human polyomavirus BK replication and sequencing analysis in a cohort of adult kidney transplant patients treated with basiliximab. Virol J, 2011; 8: 407.

6. Bechert CJ, Schnadig VJ, Payne DA, Dong J. Monitoring of BK Viral Load in Renal Allograft Recipients by Real-Time PCR Assays. Am J Clin Pathol, 2010; 133: 242-50.

7. Abdelsalam NF, Hashad DI, Salem MA, El-Wakil HS, Adam AG. Occurrence of the Polyomavirus among Kidney Transplant Recipients: A Single-Center Study. Saudi J Kidney Dis Transpl, 2014; 25(2): 285-93.

8. Kwak EJ, Vilchez RA, Randhawa P, Shapiro R, Butel JS, Kusne S. Pathogenesis and Management of Polyomavirus Infection in Transplant Recipients. Clin Infect Dis, 2002; 35: 1081-7.

9. M, Passweg J, Hirsch HH, Knowles W, Dickhenmann Klimkait T, Mihatsch M, Steiger J. Prospective study of polyomavirus type BK replication and nephropathy in renal-transplant recipients. $\mathrm{N}$ Engl J Med, 2002; 347: 488-96.

10. Vats A, Shapiro R, Singh Randhawa P, Scantlebury V, Tuzuner A, Saxena M, et al. Quantitative viral load monitoring and cidofovir therapy for the management of BK virus-associated nephropathy in children and adults. Transplant, 2003; 75: 105-12.

11. Hirsch $H H$, Randhawac $P$, and the AST Infectious Diseases Community of Practice. BK Polyomavirus in Solid Organ Transplantation. Am J Transplant, 2013; 13: 179-88.

12. Randhawa P, Ho A, Shapiro R, Vats A, Swalsky $P$, Finkelstein $S$, et al. Correlates of Quantitative Measurement of BK Polyomavirus (BKV) DNA with Clinical Course of BKV Infection in Renal Transplant Patients. J Clin Microbiol, 2004; 3: 1176-80.

13. Sung $H$, Choi BH, Pyo $Y J$, Kim $M N$, Han DJ. Quantitation of BK Virus DNA for Diagnosis of BK Virus-Associated Nephropathy in Renal Transplant Recipients. J Korean Med Sci, 2008; 23: 814-8.

14. Marinelli K, Bagnarelli P, Gaffi G, Trappolini S, Leoni P, Paggi AM, et al. PCR real time assays for the early detection of BKV-DNA in immunocompromised patients. New Microbiologica, 2007; 30: 275-8.

15. Holman CJ, Van Burik JAH, Hinrichs SH, Balfour Jr $\mathrm{HH}$. Specific Detection of Human BKPolyomavirus in Urine Samples of Immunocompromised Patients. Clin Diagn Lab Immunol, 2003; 10: 66-9.
16. Hoorfar J, Wolffs P, Rådstro P. Diagnostic PCR: validation and sample preparation are two sides of the same coin. APMIS, 2004; 112: 808-14.

17. Hayden RT, Yan X, Wick MT, Rodriguez AB, Xiong $X$, Ginocchio CC, et al. Caliendog for the College of American Pathologists Microbiology Resource Committee. Factors Contributing to Variability of Quantitative Viral PCR Results in Proficiency Testing Samples: a Multivariate Analysis. J Clin Microbiol, 2012; 50: 337-45.

18. Green RL, Roinestad IC, Boland C, Hennessy LK. Developmental Validation of the QuantifilerTM Real-Time PCR Kits for the Quantification of Human Nuclear DNA Samples. J Forensic Sci, 2005; 50: $1-17$

19. Moret $\mathrm{H}$, Brodard $\mathrm{V}$, Barranger $\mathrm{C}$, Jovenin $\mathrm{N}$, Joannes M, Andre Oletti L. New Commercially Available PCR and Microplate Hybridization Assay for Detection and Differentiation of Human Polyomaviruses JC and BK in Cerebrospinal Fluid, Serum, and Urine Samples. J Clin Microbiol, 2006; 44: 1305-9.

20. Chevaliez S, Bouvier-Alias M, Brillet R, Pawlotsky JM. Overestimation and Underestimation of Hepatitis C Virus RNA Levels in a Widely Used RealTime Polymerase Chain Reaction-Based Method. Hepatology, 2007; 46: 22-30.

21. Hoffman NG, Cook L, Atienza EE, Limaye AP, Jerome KR. Marked Variability of BK Virus Load Measurement Using Quantitative Real-Time PCR among Commonly Used Assays. J Clin Microbiol, 2008; 46: 2671-80.

22. Zhang CW, Chen XQ, Bai YH, Pan XD, Wang SL, Cai $Y$ et al. Establishment of a real-time PCR assay for simultaneously detecting human BKV and CMV DNA and itsapplication in renal transplantation recipients. Bing Du Xue Bao, 2013; 29(4): 410-4.

23. Wu CZ, Chen XQ, Wang ZY, Pan XD, Bai YH, Yang YR et al. J Virol Methods, 2014; 210: 40-4.

24. Mitui M, Leos NK, Lacey D, Doern C, Rogers BB, Park JY. Development and validation of a quantitative real time PCR assay for BK virus. Mol Cell Probes, 2013; 27: 230-6.

25. Bergallo M, Astegiano S, Sidoti F, Mantovani S, Segoloni GP, Cavallo R et al. Real-time RT-PCR assay for the quantitation of polyomavirus BK VP1 mRNA levels in urine. Mol Biotechnol, 2010; 45: 82-6. 